\title{
RANDOM REMARKS ON THE ROLE OF SOCIAL SCIENCES IN THE JUDICIAL DECISION-MAKING PROCESS IN SCHOOL DESEGREGATION CASES
}

\author{
JOHN MinOR WISDOM*
}

\section{INTRODUCTION}

It is an honor to open this timely conference. I hope that the participants, each a distinguished authority in the social sciences and school desegregation litigation, will treat with tolerance my random remarks-old hat to many-on the role of social sciences in the judicial decision-making process in school desegregation cases. The conference is timely because the twentieth anniversary of Brown $v$. Board of Education ${ }^{1}$ is a logical point at which to assess the relationship between school desegregation and the enhancement of the life chances of members of minority groups.

I have an old-fashioned fondness for Jhering, Erhlich, and Pound ${ }^{2}$ who thought of law as a means to the end of protecting social interests by the authority of the state. These are the early socio-legal thinkers whose spirits hover over this conference. Perhaps Brown and its progeny may be rationalized in accord with their thinking without doing violence to Wechsler's doctrine of neutral principles. ${ }^{3}$

The conference is especially timely for another reason. It comes less than a month after the Supreme Court's five-to-four decision in the Detroit case, Milliken v. Bradley, ${ }^{4}$ prohibiting busing across school district lines, absent proof that the school lines were drawn in a racially discriminatory manner or that state action caused interdistrict segregation.

Judges must be wary of their words, especially in discussing recent Supreme Court decisions. An important decision breeds litigation. Judges have to avoid the appearance as well as the fact of prejudging issues in cases, perhaps

\footnotetext{
* Judge, United States Court of Appeals for the Fifth Circuit. This article is an edited version of the keynote speech given on August 18, 1974 at the opening of a conference on The Courts, Social Science, and School Desegregation held at Hilton Head Island, S.C., August 18-2 1. 1974.

1. 347 U.S. 483 (1954).

2. See especially, R. Jhering, Law as a Means to an ENd (I. Husik transl. 1924); E. Ehrlich, Fundamental Principles of The Sociology of Law (W. Moll transl. 1936); Pound, A Survey of Social Interests, 57 Harv. L. Rev. I (1943); R. Pound, 3 Jurisprudence, pt. 4 (1959).

3. Wechsler, Toward Neutral Principles of Constitutional Law, 73 HARv. L. REv. 1 (1959).

4. 418 U.S. 717 (1974).
} 
yet unborn, but generated by a decision such as Milliken $v$. Bradley. I cannot say that this decision now allows the South to bring in de facto segregation, northern style, to school systems, once they are judicially declared unitary. I can safely say, however, based on the Supreme Court's opinion and the briefs in the Milliken case, that social science research appears to have had no effect on the final decision-making process in this case, but may have had a great deal to do with the lower courts decisions approving interdistrict busing for the Detroit metropolitan area. There was expert testimony by educators, one of whom is attending this conference. ${ }^{5}$ Some of the lawyers in Milliken $v$. Bradley $^{6}$ and in other important school desegregation cases are also here. They have often relied on social scientists as witnesses.

The district court first found, after evidentiary hearings, that the Detroit District School Board had drawn attendance zones, chosen school sites, and taken other action having the "natural, probable, and actual effect" of promoting segregation. ${ }^{7}$ After later hearings, the court held that the only effective relief from de facto segregation in Detroit would be to treat the urban and suburban school districts as related parts of one metropolitan area. Any remedy limited to Detroit proper would increase segregation and the flight to the suburbs. ${ }^{8}$ As we all know, of course, in many matters having nothing to do with school desegregation, the trend is toward a city and its satellites pooling their interests, voluntarily and by statute.

When the Detroit case reached the Sixth Circuit, that court, sitting en banc, in a lengthy, carefully considered opinion, affirmed the district court's decision." Judge Weick, dissenting, objected strongly: ${ }^{10}$ "The District Court was motivated in its decision by social considerations." The district court had said: "We must bear in mind that the task we are called upon to perform is a social one, which society has been unable to accomplish. In reality, our courts are called upon, in these school cases, to attain a social goal, through the educational system, by using law as a lever. $" 11$ This statement of the trial

5. Gordon Foster, Professor of Education and Director of the Florida School Desegregation Consulting Center, University of Miami.

6. Norman Chachkin, NAACP Legal Defense and Education Fund, Inc, and Nathaniel R. Jones, NAACP General Counsel.

7. Bradley v. Milliken, 338 F. Supp. 582, 587-89 (E.D. Mich. 1971), affd, 484 F.2d 215 (6th Cir. 1973), revid. 418 U.S. 717 (1974).

8. See Bradley v. Milliken, 484 F.2d $215,242-45$ (6th Cir. 1973) (quoting the umreported district court opinion). The district court designated as the "desegregation area" a region comprising fifty-four of eighty-six districts in three counties including and adjoining Detroit, see $345 \mathrm{~F}$. Supp. at $918,922-37$. The districts were further divided into clusters for desegregation. Se $345 \mathrm{~F}$. Supp. at $928-29$.

9. Bradley v. Milliken, 484 F.2d 215 (6th Cir. 1973). The court of appeals, however, vacated the district court's order and remanded the case because of the trial court's failure to join the suburban school districts as necessary parties. $I d$. at 251-52.

10. Id. at 260 .

11. 484 F.2d at 260-61, quoting a statement made at the pretrial conference by the district court. 
judge, Judge Roth, could have been made by Jhering or Erhlich, and quoted with approval by Roscoe Pound. "This is incredible!" said Judge Weick. Judges "should [not] assume to act as legislators, for which they are neither fitted nor qualified. It is enough for judges to perform their judicial function and to abide by the separation of powers doctrine provided by our Constitution." 12 It is interesting to note, however, that Judge Weick quoted ${ }^{13}$ from the Taeubers influential study, Negroes in Cities, ${ }^{14}$ and cited an article by Karl Taeuber in Scientific American. ${ }^{13}$

The Supreme Court's decision in Milliken $v$. Bradley carefully avoids any reference to social considerations. The Court decided, as a matter of law, that "absent an interdistrict violation, there is no basis for an interdistrict remedy. . . " ${ }^{16}$ But let us suppose that to bolster its conclusion and to show its general knowledge of the subject the Supreme Court had added one footnote, say footnote $11,{ }^{17}$ citing Coleman, Pettigrew, Armor, Jencks, Moynihan, Jensen, ${ }^{18}$ and other authorities for the propositions that the achievement increment of black children who are bused to obtain racial balance is not increased significantly enough to overcome the educational disadvantage of the children

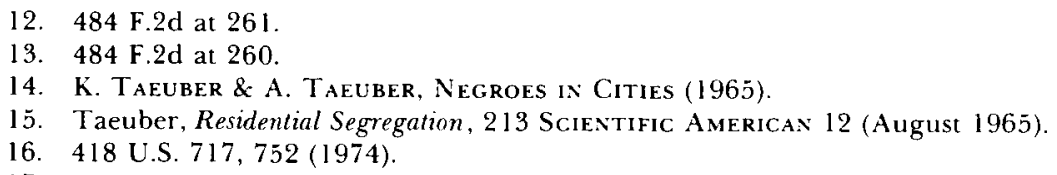

17. In Broun v. Board of Educ. the Court stated that segregation in the public schools had a detrimental effect upon the Negro children. "Whatever may have been the extent of psychological knowledge at the time of Plessy v. Ferguson, this finding is amply supported by modern authority." 347 U.S. at 494. Footnote eleven reads:

K.B. Clark, Effect of Prejudice and Discrimination on Personality Development (Midcentury White House Conference on Children and Youth, 1950): Witmer and Kotinsky. Personality in the Making (1952), c. VI; Deutscher and Chein, The Psychological Effects of Enforced Segregation: A Survey of Social Science Opinion, 26 J. Psychol. 259 (1948); Chein, What Are the Psychological Effects of Segregation Under Conditions of Equal Facilities?, 3 Int. J. Opinion and Attitude Res. 229 (1949); Brameld, Educational Costs in Discrimination and National Welfare (Maclver, ed., 1949), 44-48; Frazier, the Negro in the United States (1949), 674-81. And see generally Myrdal, An American Dilemma (1974).

18. James S. Coleman is the principal author of Equality of Educational Opportunity, also called the Coleman Report, prepared for the Department of Health, Education, and Welfare in 1966. Thomas F. Pettigrew is the principal consultant to the 1967 U.S. Commission on Civil Rights report, Racial Isolation in the Public Schools, and the author of Racially Separate or Together? which begins with the statement, "[t]his book has grown out of my deep conviction that genuine racial integration can and must be achieved in the United States." Their views differ from those of David J. Armor and Christopher Jencks on the causes for blacks falling behind whites on achievement tests. See, for example, Armor, The Evidence on Busing, in The Great School Bus Controversy 81 (N. Mills ed. 1973); C. Jencks, lNequality (1972). Frederick Mosteller and Daniel Moynihan reanalyzed the Coleman Report data in On Equality of Educational Opportunity. Arthur Jensen's views may perhaps best be seen in Jensen, How Much Can We Boost IQ and Scholastic Achievement? 39 HaRv. ED. Rev. I (1969). There is a vast amount of solid research on school desegregation, much of it by participants in this conference. But there is litte agreement on methodology or conclusions, even when the data relied on are the same as, for example, that in the Coleman Report or Rarial Isolation in the Public Schools. 
from low socioeconomic backgrounds; that the feeling of control over one's destiny has a stronger relationship to achievement than all the school factors together; that the equal protection clause may require affirmative action to integrate the schools, but integration cannot be equated with equal educational opportunity. Or, since, to put it mildly, it is difficult to find a common denominator of the conclusions of these social scientists, and others that might be cited, the footnote may have started, "See generally . . . "19 Would the decision have been said to have been based on sociology rather than law?

In any event, the Detroit case was decided opportunely for this conference. Perhaps some of the participants attending the conference may be able to peer down the road and tell us the social consequences of that decision. What will be its impact on the trend toward metropolitan-wide solutions to the financing and delivery of public services, ${ }^{20}$ or on the preservation of the inner core of cities-their historic areas, for example? What effect will it have on urban and suburban schools, on the socioeconomic gap between the races, on the educational and psychological effects of accelerated isolation of the races? A fruitful source of sociological inquiry will be to determine what data may justify an interdistrict remedy which the majority in Milliken $v$. Bradley permits when there is segregation traceable to interdistrict constitutional violations. Justice Stewart, in his concurring opinion, emphasized that interdistrict busing might be "proper, or even necessary, in other factual situations" than that presented in Milliken $v$. Bradley. ${ }^{21}$

Sociology has always played a part in the decision-making process, although frequently it comes in wearing a mask. Sometimes the mask is public policy or the interests of justice, sometimes judicial notice or common knowledge, sometimes legislative or constitutional facts. In these instances the judge, perhaps unwittingly, may be functioning as a sociologist without benefit of witnesses and solid empirical data and perhaps is treating the litigants unfairly. ${ }^{22}$

\footnotetext{
T9. The reference in Brown to Gunnar Myrdal's An American Dilemma stated: "And see generally

"In the hierarchy of citations "and see generally" ranks as the lowliest citation of authority. It has not so been ranked, however, by the uninformed critics of Brown w. Board of Educ.

20. See, e.g., the Minnesota plan for the seven county Twin Cities area, contested in Village of Burnsville v. Onischuk, 301 Minn. __ 222 N.W. 2d 523 (1974), appeal filed, 43 U.S.L.W. 3443 (U.S. Dec. 9, 1974) (No. 74-718).

21. 418 U.S. at 755 .

22. Under the guise of judicial note [footnote omitted] some courts have conducted independent researches on their own in order to learn social facts not so notorious and indisputable as to be capable of true judicial notice. [Footnote omitted.] They have not usually obtained the information from the primary sources, but rather have had resort to libraries, [footnote omitted] experts, [footnote omitted] government agencies, [footnote omitted] or even employees of an agency which is a party to the case. The greatest
} 
In Brown I Chief Justice Warren, speaking for a unanimous court, said: ${ }^{23}$

To separate [Negro school children] from others of similar age and qualifications solely because of their race generates a feeling of inferiority as to their status in the community that may affect their hearts and minds in a way unlikely ever to be undone.

For Dr. Kenneth B. Clark, who testified in several of the school cases as to his own important studies and organized the social science evidence for the plaintiffs in Brown 1 , the role of the social scientists was crucial in supplying evidence that segregation itself meant inequality. ${ }^{24}$

For Professor Edmond Cahn, one of our great legal philosophers, Chief Justice Warren's statement was a truism, "a fact of common knowledge (e.g. that a fire burns, that a cold causes snuffles . . .)." ${ }^{25}$ For him, "[s]egregation does involve stigma; the community knows it does." ${ }^{26} \mathrm{Dr}$. Clark's studies were limited in that they did not isolate the effect of segregated schooling from non-school factors such as the effect of a disadvantaged socioeconomic status or of family background. I tend to agree with Edmond Cahn. I too should hate to think that the constitutional right of Negroes not to be segregated in education or in any other segment of American life rested on the social science evidence brought forth in Brown.

Many leaders in the massive resistance to Brown ignored or did not know that Chief Justice Warren's statement had its counterpart in Plessy v. Ferguson, ${ }^{27}$ the 1896 case that sanctioned Jim Crow laws under the "separate but equal" doctrine. In Plessy, the author of the opinion, whose name, significantly, was Brown, observed:28

We consider the underlying fallacy of the plaintiff's argument to consist in the assumption that the enforced separation of the two races stamps the colored race with a badge of inferiority. If this be so, it is not by reason of anything found in the act, but solely because the colored race chooses to put that construction upon it.

objection to such practice is the disregard of the parties to the litigation, who are given no opportunity to be heard. [Footnote omitted.]

Note, Social and Economic Facts-Appraisal of Suggested Techniques for Presenting Them to the Courts, 61 Harv. L. Rev. 692, 697 (1948). See also Wyzanski, A Trial Judge's Freedom and Responsibility, 65 HARV. L. REV. 1281, $1295-96$ (1952).

23. 347 U.S. at 494.

24. Clark, The Desegregation Cases: Criticism of the Social Scientist's Role, 5 VILL. L. Rev. 224-26 (1959).

25. Cahn, Jurisprudence, 30 N.Y.U.L. REv. 150, 161 (1955).

26. Id. at 158. See Black, The Lawfulness of the Segregation Decisions, 69 Yale L.J. 421, 424-26 (1960), in which Professor Charles Black wrote that it is a "canard" to say that "principal reliance was placed on the formally 'scientific' authorities, which are relegated to a footnote and treated as merely corroboratory of common sense." Id. at 430 n. 25. See also Pollak, Racial Discrimination and Judicial Integrity: A Reply to Professor Wechsler, 108 U. PA. L. Rev. 1, 26-30 (1959).

27. 163 U.S. 537 (1896). Barton Bernstein, for one, says: "[S]ociological and psychological theories controlled the courts [sic] decision" in Plessy. Bernstein. Plessy v. Ferguson: Comservative Sociological Jurisprudence, 48 J. NEGro Hist. 196, 198 .(1963).

28. 163 U.S. at 551 . 
This is no less a sociological statement than Chief Justice Warren's language in Brown.

The road is not smooth for the use of social science evidence in the courts. Testimony of experts for the plaintiffs forces the defendants to come forward with experts. If the trial is prolonged and played up in the communications media, the public impression is that the court is elevating sociology at the expense of law. And trial judges, who have less insulation than appellate judges, are sensitive to public opinion. There are not many Frank Johnsons, Bryan Simpsons, Herbert Christenberrys, and Skelly Wrights. All judges have cut their eyeteeth on the theory that they fill in only the tiniest of interstices between existing rules, and a Holmes or a Cardozo does not come along every day to distinguish between the expansible and the non-expansible interstices. $^{29}$ Judge Weick's observation in Milliken represents the point of view most lawyers and laymen share: judges should stay within the judicial function; social considerations are for legislators. ${ }^{30}$

Segregationists, to a man, criticized the Supreme Court's holding in Brown as one that was based on sociology rather than law, as if the two must be antithetical rather than closely related or complementary. For many uninformed people, even now, Gunnar Myrdal was the chief authority the Court relied upon, although his was only one of several names in a footnote. Even James Reston, writing for the New York Times, subtitled his article on the case, "Court Founded Its Segregation Ruling on Hearts and Minds Rather than Laws." ${ }_{11}$ On this point many advocates of integration were willing to agree with Reston. They regarded the resort to social science testimony as a new approach to school desegregation, and they were proud of the ability and trial strategy of the plaintiffs' lawyers.

As everyone knows, the Supreme Court held in Brown I that "separate but equal ... educational facilities are inherently unequal." 32 And, "even though the physical facilities and other 'tangible' factors may be equal," segregation "deprive[s] the children of the minority group of equal educational opportunities." 33

There are certain aspects of the opinion that diminish the importance many persons attach to the sociological proof of harm caused by segregated schooling. The Supreme Court, in its opinion, did not refer to the testimony of Dr. Kenneth Clark, who testified in the three cases consolidated with Brown v. Board of Education, and to other witnesses, although more than forty social

29. Justice Holmes, dissenting in Southern Pacific Co. v. Jensen, 244 U.S. 205,221 (1917), said: "Mr. Justice Cardozo used this flashing epigram' in developing his own theory that in every department of the law . . the social value of a rule has become a test of growing power and importance." "B. Cardozo, The Nature of the Judicial Process 27 (1921).

30. Bradley v. Milliken, 484 F.2d 215,261 (6th Cir. 1973) (dissenting opinion).

31. Reston, A Sociological Decision, N.Y. Times, May 18, 1954, at 14, col. 4.

32. 347 U.S. at 495 .

33. 347 U.S. at 493 . 
scientists and educators testified in four of the five school desegregation cases $^{34}$ that filled four volumes of the record. The Court did not refer to a lengthy statement, filed as an appendix to the plaintiffs' briefs, signed by thirty-two sociologists, anthropologists, psychologists, and psychiatrists. ${ }^{35}$ Moreover, the Court did not, in terms, overrule Plessy v. Ferguson. That case is yet to be specifically overruled. Justice Douglas still cites it as viable authority $^{36}$ and has pointed out that Milliken $v$. Bradley is a retreat from Plessy v. Ferguson. ${ }^{37}$

The transcript of the oral argument before the Supreme Court in the first round of the segregation cases shows that the plaintiffs lawyers ${ }^{38}$ stressed the inherent vice of racial classification rather than the harmful lack of equal educational opportunity. ${ }^{39} \mathrm{Mr}$. Robert Carter, now Judge, in the first argument in Brown in 1952, contended that under the plaintiffs' theory, "[the Supreme Court does] not have to reach the [sociological] findings, because we maintain that this is an unconstitutional classification." ${ }^{40} \mathrm{Mr}$., now Justice, Marshall, arguing a companion case during reargument in 1953, asserted: "[Y]ou cannot separate people or denote that one is to go here and one is to go there even if the facilities are absolutely equal." 41 Also in the reargument, Mr., now Judge, Robinson argued that the purpose of the fourteenth amendment was

34. The cases referred to were Brown $v$. Board of Educ., on appeal from the Kansas federal district court, Briggs $v$. Elliott, on appeal from a federal district court in South Carolina, Davis $v$. County School Bd., on appeal from a federal district court in Virginia, Gebhart v. Belton, on cert. to the Supreme Court of Delaware, and Bolling $v$. Sharpe, on cert. to the Court of Appeals for the District of Columbia. The first four cases were argued separately but resulted in a consolidated opinion, Brown v. Board of Educ., 347 U.S. 483 (1954). The latter case resulted in the opinion in Bolling v. Sharpe, 347 U.S. 497 (1954). Together the cases are often referred to as the Segregation Cases.

35. The Effects of Segregation and the Consequences of Desegregation: A Social Science Statement, reprinted in 37 MIN. L. REv. 427 (1953) (appendix to appellants' briefs in Brown v. Board of Educ., Davis v. County School Bd., and Briggs v. Elliott, argued together before the Supreme Court and for which the Court issued a consolidated opinion, 347 U.S. 483 (1954)).

36. "But Plessy v. Ferguson has not yet been overruled on its mandate that separate facilities be equal." Gomperts v. Chase, 404 U.S. 1237, 1240 (1971). Again, dissenting in Spencer v. Kugler, 404 U.S. 1027, 1031 (1972), Justice Douglas, wrote: "But there can be de facto segregation without the State's being implicated in the creation of the dual system and it in such situations that Plessy's mandate that separate facilities be equal has continuing force." Gayle v. Browder, 352 U.S. 903 (1956), aff'g per curiam 142 F. Supp. 707 (M.D. Ala. 1956), however, may be read as silently overruling Plessy v. Ferguson.

37. Dissenting opinion, Milliken v. Bradley, 418 C.S. at 759.

38. Three of the better known attorneys who represented the plaintiffs are Thurgood Marshall, now on the Supreme Court; Spottswood Robinson, now on the Court of Appeals for the District of Columbia; and Robert L. Carter, former General Counsel of the NAACP and now District Judge in the Southern District of New York.

39. Kaplan, Segregation Litigation and the Schools-Part II: The General Northern Problem, 58 Nw. U.L. REv. 157, 173 (1963). Carter has concluded that the principal impact of Brown has been its encouragement of the idea among blacks that equality may be demanded as a right, not petitioned for as a favor. See Carter, The Warren Count and Desegregation, 67 Mich. L. Rev. 237, 246-48 (1968).

40. 21 U.S.L.W. 3161,3163 (Dec. 16, 1952).

41. 22 U.S.L.W. 3157,3159 (Dec. 15, 1953) 
to prevent the imposition of "governmentally cast distinctions, predicated upon race." 42

Those who have studied Plessy $v$. Ferguson in depth will see a similarity between this argument and that of Albion W. Tourgée, attorney for Plessy, whose words inspired the first Justice Harlan. Tourgée said, ${ }^{43}$

Why not require all colored people to walk on one side of the street and whites on the other. One side of the street may be just as good as the other .... The question is not as to the equality of the privileges enjoyed, but the right of the State to label one citizen as white and another as colored in the common enjoyment of a public highway.

Tourgée declared, in words Justice Harlan paraphrased: "There is no caste here. . . Justice is pictured blind and her daughter, The Law, ought at least to be color-blind. $" 44$

Wirhin a short time after the segregation cases, the Court, in a number of per curiam opinions simply citing Brown, struck down segregation on public golf courses, ${ }^{45}$ on beaches, ${ }^{46}$ in parks, ${ }^{47}$ in seating in public facilities, ${ }^{48}$ in athletic contests, ${ }^{49}$ and in other situations where there was separation by racial classification, although there was no sociological evidence of harm, and no possibility of harm except from the stigma inherent in racial segregation.

These cases suggest that the Court itself interprets Brown as resting on the principle that forced separation of the races is an invidious classification violative of the equal protection clause. In this respect, it is significant that in Brown the Court relied on Sweatt v. Painter" ${ }^{50}$ and McLaurin v. Oklahoma State Regents,${ }^{51}$ two decisions which were concerned with segregated higher education. The Court noted that it had, in those cases, resorted to "intangible considerations" which were "incapable of objective measurement." ".2 These considerations did away with the necessity of relying on social science testimony which, if leaned on heavily, might create the impression that the Court was legislating social goals into the law. I think, therefore, that while Professor Cahn may have overstated the ineffectiveness of the sociological evidence in Brown, that evidence played only a minor role in the decision..$^{53}$

Whatever effect the Court gave to the social science testimony, unarticu-

42. 22 U.S.L.W. at 3157.

43. Brief for the Plaintiff in Error at 29, Plessy v. Ferguson, 163 U.S. 537 (1896).

44. Brief for the Plaintiff in Error at 19, Plessy v. Ferguson, 163 U.S. 537 (1896).

45. Holmes v. Atlanta, 350 U.S. 879 (1955).

46. Mayor \& City Council of Baltimore City v. Dawson, 350 U.S. 877 (1955).

47. New Orleans City Park Improvement Ass'n v. Detiege, 358 U.S. 54 (1958).

48. Johnson v. Virginia, 373 U.S. 61 (1963); Schiro v. Bynum, 375 U.S. 395 (1964).

49. State Athletic Comm'n v. Dorsey, 359 U.S. 533 (1959).

50. 399 U.S. $629(1950)$.

51. 339 U.S. 637 (1950).

52. 347 U.S. at 493.

53. But see Fiss, Racial Imbalance in the Public Schools: The Constitutional Concepts, 78 HaRv. L. REv. 564, 590-94 (1965). 
lated in the opinion, Brown was the product of irresistible social and political forces-"an idea whose time had come." 54 But the opinion broke no new ground in judicial methodology. The Court rested its decision on the content of the fourteenth amendment in the context of the time, confident that it was interpreting the Constitution as a living document for all times. Had there been no social data in the record, no footnote eleven, Chief Justice Warren, backed by all the Court, would still have been able (1) to start with the premise, as he did, that "we cannot turn the clock back," but "must consider public education in the light of its full development and its present place in American life ${ }^{*}{ }^{55}$ (2) to argue in a traditional judicial manner, as he did, by analogy from Sweatt and McLaurin, that "intangible considerations" apply with "added force to children in grade and high school"; 56 and (3) to conclude that "separate but equal" is "inherently unequal. " 57 The social science evidence was the kind of support a court likes to find in a record to lend factual and scientific aura to a result sustainable by other, perhaps purely abstract and sometimes formalistically legal, considerations, but dictated by the moral necessity of changing social attitudes.

Paradoxically, I believe that the reaction of many vocal critics of Brown who characterized the decision as based on sociology, rather than law, has had a healthy effect on the use of social science research in the decisional process. Courts, since Muller v. Oregon, have respected the "Brandeis-type" brief supporting socially-oriented legislation. ${ }^{58}$ In $M u l l e r$, however, and in similar cases, as Professor Paul Freund has pointed out, ${ }^{59}$ the data was used to sustain social legislation and might be considered legislative or constitutional facts of which a legislature might be presumed to have knowledge. In and after Brown, this type of extra-legal evidence has been used to attack legislation. The criticism of Brown focused the attention of judges and lawyers on the propriety and value of empirical data and social studies at both the trial and appellate levels. Statistics became more important to courts. "[F]igures speak and when they do, Courts listen . ..," Chief Judge John Brown of the Fifth Circuit Court of Appeals has written. ${ }^{60}$

What seemed at first to be antagonism between social science and law has now developed into a love match. What began in the field of education spread to many other fields. In case after case the Fifth Circuit, among other courts,

54. "There is no army greater than an idea whose time has come" is a statement made famous by Senator Everett Dirksen on May 19, 1964, at a press conference concerning passage of the Civil Rights Act of 1964 , but Victor Hugo said it first.

55. 347 U.S. at 492 .

56. 347 U.S. at $493-94$.

57. 347 U.S. at 495 .

58. Muller v. Oregon, 208 U.S. 412 (1908).

59. Freund, Review of Facts in Constitutional Cases, in Supreme Court axd Supreme. Law 47, 49-50 (E. Cahn ed. 1954); P. Freund, On Understanding the Supreme Court 88-90 (1949).

60. Brooks v. Beto, 366 F.2d 1, 9 (5th Cir. 1966), cert. denied, 386 U.S. 975 (1967). 
has relied on studies developed by social scientists and other scientists to show pollution, unlawful exclusion of blacks from the jury system, employment discrimination, arbitrary or discriminatory use of the death penalty, discrimination against women, the need for reapportionment, and the cure for malapportionment of various public bodies. Throughout the country, educational centers in various universities have prepared desegregation plans at the request of school boards and district judges.

\section{III}

Since Brown, in school cases involving de jure segregation, findings of fact are no longer needed to establish a substantive constitutional violation. This is the value of the de jure/de facto dichotomy-if it has a value. But fact findings are still needed in devising a remedy in de jure cases.

In de facto segregation cases, Professor Fiss has pointed out that "a principle requiring equality of educational opportunity must be abstracted from the equal protection clause. . ."61 In applying this principle, the court must make "the empirical judgment whether the opportunity afforded Negro children is significantly and systematically inferior to that afforded others. "62 This inequality may be apparent on its face. When it is not, a court is required to probe beyond the nominal level to determine whether this factual inequality exists. A court must make another judgment, "whether there is an adequate justification for any existing substantial difference in educational opportunity. ${ }^{63}$

Ten years ago, advocates of segregation asked the courts to make such a judgment. In Stell v. Savannah-Chatham County Board of Education, ${ }^{64}$ a de jure case arising in Georgia, parents of white children intervened. They sought to justify racial segregation on the ground that social science research had demonstrated that it would be educationally harmful to black children from disa':vantaged environments to be forced into competition with white children. Their proof rested on the testimony and studies of several social scientists, some of whom one would have to acknowledge as legally qualified to testify. ${ }^{65}$ Counsel for the black plaintiffs was Mrs., now Judge, Constance Baker Motley, ${ }^{66}$ who had ably represented James Meredith in desegregating the University of Mississippi. She objected to the social science testimony as irrelevant, in light of the Brown case. District Judge Scarlett, who had a long record of re-

61 . Fiss, supra note 53 , at 588 .

62. Id.

63. Fiss, supra note 53 , at $\mathbf{5 8 9}$.

64. 220 F. Supp. 667 (S.D. Ga. 1963), rev'd, 333 F.2d 55 (5th Cir. 1963), cert. denied, 379 U.S. 933 (1964).

65. For example, Dr. Henry Garrett had been the head of the Department of Psychology at Columbia University and had taught there for more than thirty years.

66. Constance Baker Motley is now U.S. District Judge in the Southern District of New York. 
versals by the Fifth Circuit in civil rights cases, held that " $[t]$ he factual nature of the finding of injury through segregation in Brown opened the door" to the intervenors' proof. ${ }^{67}$ On the basis of the "scientific" evidence, he found that Negro children tested well below white children in various tests and that there was "no evidence whatsoever ... to show that racial integration of the schools could reduce these differences"; the differences are "attributable in large part to hereditary factors." ${ }^{8} \mathrm{He}$ added: "Whatever psychological injury may be sustained by a Negro child . . . is increased rather than abated by forced intermixture . . . .69 Accordingly, Judge Scarlett dismissed the plaintiffs' suit to desegregate Savannah schools. The Fifth Circuit did not permit Judge Scarlett to stand Brown on its head. Our court peremptorily reversed the decision and reprimanded him for abuse of his discretionary powers. ${ }^{70}$

It is interesting that in the Detroit case, ${ }^{71}$ the trial judge, Judge Roth, permitted the suburban school boards to take the deposition of Dr. David Armor who earlier had written, based on his studies of various busing "experiences," that "busing is not an effective policy instrument for raising the achievement of black students or for increasing interracial harmony."72 Judge Roth later refused to receive it in evidence on the ground that it was irrelevant; it represented "a new rationale for a return to the discredited 'separate but equal' policy."73 Indeed, he excluded all evidence on the questionable value of crossdistrict busing. As noted earlier, in the Sixth Circuit

67. 220 F. Supp. at 678 .

68. 220 F. Supp. at 683 .

69. $220 \mathrm{~F}$. Supp. at 684 .

70. 333 F.2d 55 (5th Cir. 1963), cert. denied, 379 U.S. 933 (1964). In a case similar to Stell, District Court Judge Mize in Evers v. Jackson Municipal Separate School Dist., 232 F. Supp. 241 (S.D. Miss. 1964), found from "uncontradicted" testimony by seven "distinguished scientists" that:

The evidence was conclusive to the effect that the cranial capacity and brain size of the average Negro is approximately ten per cent less than that of the average white person of similar age and size, and that brain size is correlated with intelligence.

Id. at 247. He also concluded from other evidence

that white and Negro pupils of public school age have substantially different educational aptitudes and learning patterns which are innate in character and do not arise out of economic or social circumstance and which cannot therefore be changed or overcome by intermixed schooling ....

Id. at 248 . He thus concluded that segregation of races was the only reasonable classification by the state and that Brown need not be followed under either res judicata or stare decisis. However, Judge Mize struck down the segregation employed on grounds that it was bound by prior Fifth Circuit holdings.

Although it is contrary to the facts and the law applicable thereto, this Court feels that it is required to enter an order making permanent the temporary injunction heretofore entered herein ....

Id. at 255 .

71. Milliken v. Bradley, 418 U.S. 717 (1974), rev'g 484 F.2d 215 (6th Cir. 1973), aff'g 345 F. Supp. 914 (E.D. Mich. 1972), and 338 F. Supp. 582 (E.D. Mich. 1971).

72. Armor, The Evidence on Busing, 28 PuB. InTERest 90, 115 (Summer 1972) (emphasis in original).

73. Bradley v. Milliken, 345 F. Supp. 914, 921 (E.D. Mich. 1972). 
Court of Appeals, Judge Weick in his dissent, without citing Stell, concluded, as had Judge Scarlett in Stell, that sociological opinions and evidence should have been admitted because the Supreme Court had rested its decision in Brown on sociological data. ${ }^{74}$

At this stage in school desegregation, when the nature of the remedy is important and district courts have broad latitude in using their equitable powers, social science is certain to play an important part in the decisional process.

In 1971, in Swann v. Charlotte-Mecklenburg Board of Education, ${ }^{75}$ the Supreme Court dealt with de jure segregation in the Charlotte, North Carolina school system. The mandate in all such cases is to dismantle the dual school system lock, stock, and barrel. But the question of how to dismantle is the door through which social science research enters. Racially neutral plans may not be sufficient. Affirmative remedial action is required: for example, in the appropriate site selection of new schools, pairing and grouping of noncontiguous school districts, faculty ratios, and greater representation of blacks at the administrative level. However, the most obvious and effective remedy is busing of students. This is the remedy that has worked in the South, certainly in the non-metropolitan areas.

In Swann the Supreme Court unequivocally approved busing as a tool of school desegregation-subject to certain conditions. The conditions are unspecific: "the time of distance of travel [must not be] so great as to either risk the health of the children or significantly impinge on the educational process." 76 This is an invitation, if not an advice, to parents and to school boards to produce social scientists as witnesses. It will then be the duty of the trial judge to weigh their testimony and to make findings showing the correlation between the proposed busing and (1) "the health of children to be bused" and (2) the extent to which busing may "impinge on the educational process." If such a case reaches the level of the courts of appeals and the Supreme Court, the appellate court must decide whether the evidence is sufficient to support the trial judge's finding. I expect white parents to come forth some day with social scientists producing data perhaps in the form of testimony and studies by David Armor or Christopher Jencks showing that busing raises the achievement level so slightly that it is not worth the trauma in individual cases or the friction it causes in the community; that the socioeconomic background of a child is a more significant factor in achievement tests than attending a desegregated school, but that this factor is inextricably bound with ressidential patterns, difficult if not impossible to break; that school achievement tests bear only a slight relation to economic achievement or life chances

\footnotetext{
74. Bradley v. Milliken, 484 F.2d 215, 265 (6th Cir. 1973).

75. 402 U.S. 1 (1971).

76. 402 U.S. at $30-31$.
} 
after children have finished their schooling. That kind of sociological evidence, if we may call it evidence, was in Dr. Armor's excluded deposition in the Detroit case. The courts of appeals and the Supreme Court have not ruled on the relevancy of such testimony under Swann. In the Fourth Circuit, however, Judge Sobeloff, in a special concurring opinion in Brunson, ${ }^{77}$ gave it short shrift as a return, under another name, to the doctrine of the inherent inferiority of blacks as against whites. If such testimony based on social studies is admissible under the Swann proviso, proponents of busing will have to come forward with countervailing social science evidence.

Keyes $v$. School District No. $1^{78}$ arose in a more difficult context for the minorities seeking desegregation. In Denver there is a tri-ethnic population; for decades blacks and Hispanos ${ }^{79}$ were concentrated in the central core of the city. But there had never been de jure segregation in Denver in the sense that schools had been segregated by statute, as they had been in the South. The district court found, however, that in one residential section there had been acts of de jure segregation stemming from deliberate, intentional segregative policies on the part of school officials-as demonstrated by a policy of concentrating blacks in black schools, by new school construction, and by boundary changes for school zones. ${ }^{80}$ Racial separation in the school system as a whole, however, was not attributable to de jure segregation. The court held that "an equal educational opportunity is not being provided at the . . segregated [minority] schools . . .," 81 and therefore ordered those schools desegregated. The district court relied on the testimony, among others, of Dr. James D. Coleman, author of the Coleman Report, Dr. Neil Sullivan, Commissioner of Massachusetts State Board of Education, and Dr. Robert O'Reilly, Assistant Director of Research at New York State Department of Education.

The Supreme Court held, first, that the illegal acts forming the basis of the de jure finding had reciprocal effects throughout the system and therefore called for a system-wide remedy; and that the de jure finding as to part of the system raised a presumption that racial imbalance elsewhere was due to a policy of segregation which shifted the burden of proof to the school district.

The Court adopted a limited definition of de jure segregation: "the differentiating factor between de jure segregation and so-called de facto segregation . . . is purpose or intent to segregate." 82 In a Swann-type case it would relate to the substantive constitutional violation as well as to remedy. Social scientists would have to study and testify on the purpose and natural effect

77. Brunson v. Board of Trustees of School Dist. No. 1, 429 F.2d 820, 823, 826 (4th Cir. 1970) (separate concurring opinion).

78. 413 U.S. $189(1973)$.

79. Hispanos is the term used by Justice Brennan writing for the Court in Keyes.

80. See 313 F. Supp. 61, 64-69 (D. Colo. 1970), aff d in part and rev'd in part, 445 F.2d 990 (10th Cir. 1971), modified and remanded, 413 U.S. 189 (1973).

81. 313 F. Supp. at 83 .

82. 413 U.S. at 208 (emphasis by the Court). 
of residential segregation, site selection of schools, "feeder" schools, tracking, and other factors from which an "intention" to segregate blacks and Hispanos could be inferred. ${ }^{83}$ Then, if busing is employed as a remedy, the requirements of the Swann proviso will have to be met, without crossing school district lines.

In Keyes, the Court remanded the case for findings, and on remand the trial court found that the policies and practices of the school board established de jure segregation by the creation of a dual school system. ${ }^{84}$

IV

The Fifth Circuit includes the states of Florida, Texas, Georgia, Louisiana, Alabama, and Mississippi. I have served on that court since July 1957. I remember that in 1960, six years after Brown, the admission of three little Negro girls to one class in one white school in New Orleans was regarded as a great stride forward. I remember when transfers under the fraudulent pupil placement law and grade-a-year plans were considered radical. ${ }^{85}$ When I see Tulane play the University of Mississippi in a football game with black players on each team, I think of the riots and violence that took place when James Meredith became the first black to attend the University of Mississippi. Only a few months ago, James Meredith won the Democratic nomination for Congress in his district. Today, five of Alabama's six best basketball players are black. Recently Governor George Wallace appointed a black to his cabinet. Spectacular turn-arounds do indeed show that blacks have come a long way since 1954. And I am proud that our court, among other federal courts, has contributed to recognition of the civil rights of minorities.

Nevertheless, I have a nagging feeling that it is not how far the blacks have come that is important, but how far they still have to go. It is particularly disturbing to see a white school become a desegregated school, then a black school; to see the black population in New Orleans and Atlanta public schools increase in ten years from 37 per cent to nearly 80 per cent-to 83 per cent in the seventh, eighth, and ninth grades. It is even more disturbing to know that a large number of the 20 per cent of the students who are white have a socioeconomic background similar to that of the 80 per cent. The effect is to es-

\footnotetext{
83. See 413 U.S. at $211-12$.

84. See Keyes v. School Dist. No. 1, 368 F. Supp. 207, 209-10 (D. Colo. 1973).

85. The Supreme Court in Shuttlesworth v. Birmingham Bd. of Educ, 258 U.S. 101 , aff'g 162 F. Supp. 372 (N.D. Ala. 1958), gave its approval to the use of pupil placement laws as a desegregation device. Such laws allowed (black) students to apply to transfer from their segregated schools to schools of the opposite race (white schools) in their district. All too frequently, however, a further barrier was superimposed on the pupil placement system, that being the grade-a-year limitation so that only one grade of students could request transfer the first year of the program and one additional grade each succeeding year. The combined programs effectively retarded significant integration for years. When it finally became clear that their purpose and effect was to frustrate integration, their application was enjoined. See also Read, Judicial Evolution of the Law of School Integration Since Brown v. Board of Education, 39 Law \& Contemp. Prob. no. 1, at 7, 19 nn. 48 \& 49 (1975).
} 
tablish an inelastic caste system. The affluent whites have sent their children to private schools. Most of the middle class whites, association with whom would produce a social class climate favorable to blacks in schools, have fled to the suburbs or sent their children to private schools. Apparently, too, the blacks accepted in private schools come from upper and middle class Negro families. The Detroit case will unquestionably increase the social stratification. Blacks, Hispanos, and disadvantaged whites will remain in the inner core of decaying cities, trapped in a vicious circle that, like all circles, has no definable beginning or end, but does have describable parts: inferior schools, poor housing, and low socioeconomic status. I can understand, therefore, the disillusionment black nationalists have with the progress and effectiveness of school desegregation. I can understand how separation of the races, if it means local control by blacks for blacks, may generate not the feeling of inferiority which the Supreme Court found in Brown, but a feeling of pride and respect-if the quality of education can be raised and economic opportunity increased. I do not approve of separatism under the guise of decentralization, or under any guise, but I think that I understand its motivation. Blacks suffer from a special stigma not carried by other deprived groups. It is what Professor Charles Black refers to as "walled-off inferiority";86 a legacy of three centuries of slavery and segregation, one that was legitimized in Dred Scott. ${ }^{87}$

I have received some enlightenment but very little comfort from the social science studies I have read. Perhaps, as Dean Frank T. Read has said, "One tool-the constitutional command of equal educational opportunity for all races articulated in Brown-cannot and should not be expected to solve alone the problem of segregated education." ${ }^{88} \mathrm{He}$ is right, of course. Judges should profit from other disciplines. In a sense, a judicial decision represents social science in action. Judges should acquire more knowledge of the social sciences to enable them to fulfil their policy-making function of using law as a means to the ends of serving society wisely and to its good.

Still, I have a deep conviction that the moral philosophy underlying the principle of equality established in the Second American Constitution that arose from the ashes of the Civil War is the primary source of hope for civilized racial relations in an integrated society. ${ }^{89} \mathrm{I}$ cannot extract this hope from

86. Black, The Lawfulness of the Segregation Decisions, 69 YALE L.J. 421,427 (1960).

87. Scott v. Sand ford, 60 U.S. (19 How.) 393 (1857).

88. Read, supra note 85 , at 48 .

89. The task the appellate courts are really engaged in is deciding what the law should be

But, at least in some cases, appellate judges may view a decision as one which ought to be based on moral or ethical imperatives. The point is that in these circumstances social science research may have relatively little to add. For example, the impression one gathers after reading Brown $v$. Board of Education is that the social science evidence on the effects of racially segregated schools made little difference to the case's outcome. Even if the social science evidence had been considerably more open to the question than it was, the Court would likely have concluded that confining children of different races to separate schools violated the 
my limited exposure to social science studies of the relationship between segregation and public education.

fourteenth amendment's equal protection clause because it was "morally wrong," if for no other reason.

Lochner, Some Limits on the Application of Social Science Research in the Legal Process, 1973 LAw \& Social Order 815, 838-39. 